\title{
$\operatorname{Pr}$ 系 ZnO バリスターの粒成長と粒界相の生成に及ぼす 焼成温度と䨌囲気の影響
}

\author{
志田雅人・全 是鎔・脇谷尚樹・篠暗和夫・水谷惟恭 \\ 東京工業大学工学部無機材料工学科, 152 東京都目黒区大岡山 2-12-1
}

\section{Effect of the Sintering Temperature and Atmosphere on the Grain Growth and Grain Boundary Phase Formation of Pr-Doped ZnO Varistor}

Masato SIDA, Seong-Yong CHUN, Naoki WAKIYA, Kazuo SHINOZAKI and Nobuyasu MIZUTANI Department of Inorganic Materials, Faculty of Engineering, Tokyo Institute of Technology, 2-12-1, O-okayama, Meguro-ku, Tokyo 152

\begin{abstract}
Effect of sintering temperature, atmosphere and concentration of Pr oxide on the grain growth and grain boundary formation of Pr-doped $\mathrm{ZnO}$ was investigated. Grain size of $\mathrm{ZnO}$ was maximized at composition of Pr $0.5 \mathrm{~mol} \%$ and grain growth rate and weight loss rate of $0.5 \mathrm{~mol} \% \mathrm{Pr}$-doped $\mathrm{ZnO}$ increased drastically above $1350^{\circ} \mathrm{C}$, regardless of the sintering atmosphere. The morphology of grain boundary in samples fired above $1350^{\circ} \mathrm{C}$ was strongly affected by the sintering atmosphere. The grain growth rate was proportional to $1 / n$-th power of time, with $n=4.5$ between $1300^{\circ} \mathrm{C}$ and $1400^{\circ} \mathrm{C}$ and $n=2.2$ at $1500^{\circ} \mathrm{C}$. An exothermic peak in DTA was observed at $1380^{\circ} \mathrm{C}$, which indicated the formation of a liquid phase.

[Received July 3, 1995; Accepted October 3, 1995]
\end{abstract}

Key-words : ZnO, Praseodymium, Grain growth, Grain boundary, Varistor

\section{1. 緒 言}

$\mathrm{ZnO}$ バリスターの電流-電圧特性は焼成温度や雾囲気, 添加物の濃度, $\mathrm{ZnO}$ の粒径などによって大きく左右され る1) 7). $\mathrm{ZnO}$ への添加物は $\mathrm{Bi}_{2} \mathrm{O}_{3}$ と $\mathrm{Pr}$ 酸化物のいずれか である(8),9). $\operatorname{Pr}_{6} \mathrm{O}_{11}$ 添加 $\mathrm{ZnO}$ では, 添加した $\mathrm{Pr}_{6} \mathrm{O}_{11}$ が焼 成中, $\mathrm{Pr}_{2} \mathrm{O}_{3}$ に還元され酸素を放出しその酸素が化学吸着 して界面準位を形成すること年 12) $\mathrm{ZnO}-\mathrm{Co}_{3} \mathrm{O}_{4}-\mathrm{Pr}_{6} \mathrm{O}_{11}$ 系で液相の生成による微構造や電気特性に及ぼす影響につ いて13) 報告されている。しかし, $\mathrm{Pr}_{6} \mathrm{O}_{11}$ の融点は約 $2000^{\circ} \mathrm{C}$ 高温であるため, バリスターの焼成温度で液相 焼結をしているとは単純に考えにくく, 焼結や粒成長の機 構はまだ十分には明らかになっていない。本研究では $\mathrm{Pr}$ 系 $\mathrm{ZnO}$ バリスターにおいて，Prの添加による粒成長を添 加量, 焼成温度や雲囲気との関係から詳細に調べ, 粒界相 の生成やPrの液相生成を示唆するような知見が得られた ので報告する.

\section{2. 実験方法}

\section{1 試料の合成}

原料に $\mathrm{ZnO}$ (高純度化学研究所製, 純度 $99.9 \%$ ), $\operatorname{Pr}_{6} \mathrm{O}_{11}$ （高純度化学研究所製, 純度 $99.9 \%$ ) を用いた. 試料の組成 は, $\mathrm{ZnO}: \mathrm{PrO}_{1.83}=(100-X): X$ に求いて $X=0,0.01$, $0.05,0.1,0.5,1,5$ 及び 20 となるように原料を秤量し，ア ルコールを用いたボールミルで湿式混合し, 乾燥後, ナイ ロンメッシュに通して造粒した。なお $\mathrm{ZnO}$ 原料の平均粒 径は約 $7 \mu \mathrm{m}$ であった。

\section{2 試料の焼成}

造粒した粉末を直径 $10 \mathrm{~mm}$ の金型を用いて, $1 \mathrm{t} / \mathrm{cm}^{2}$ の 圧力下で, 厚さが $2 \sim 3 \mathrm{~mm}$ のペレットになるように成形
した。得られた成形体を $\mathrm{N}_{2}$, air 及び $\mathrm{O}_{2}$ 雾囲気で $300^{\circ} \mathrm{C} / \mathrm{h}$ の昇温速度で $1200 \sim 1500^{\circ} \mathrm{C}$ の各温度まで昇温し，0～ $50 \mathrm{~h}$ 焼成した。

\section{3 試料の評価}

試料の相の同定及び格子定数の測定には粉末 X 線回折 装置（Philips 製，PW1700）を用いた。微構造観察には 走査型電子顕微鏡（SEM；日本電子製， JSM-T200）を 用い，平均粒径及び粒径分布を測定するのにリニアイン ターセプト法を用いた，焼成したペレットから粒界相たけ を取り出すために, $\mathrm{HF}: \mathrm{HNO}_{3}: \mathrm{HCl}: \mathrm{H}_{2} \mathrm{O}=5: 5: 20$ : 700 体積比で作ったエッチング液にペレットを室温で $24 \mathrm{~h}$ 浸して，ZnOだけ溶かし，残った粒界相を沪過して得る 方法を用いた。分離した粒界相の観察には SEM 及び透過 型電子顕微鏡（TEM; 日本電子製, JEM-200CX）を用 いた。 また粒界相の組成を分析するため，TEM に装着し ているエネルギー分散型X線分析装置 (Philips 製, EDAX PV9800）及び ICP 発光分光分析装置（セイコー 電子工業製, SPS1500VR）を用いた。高温での液相生成 の有無を調べるため, 昇温速度 $10^{\circ} \mathrm{C} / \mathrm{min}$ で, $\mathrm{N}_{2}$ ガスを流 しながら， $1500^{\circ} \mathrm{C}$ な゙自作の示差熱分析装置を用いて DTA 測定を行った.

\section{3. 結果と考察}

\subsection{Pr 添加量と粒成長}

図 1 に air 中 $1350^{\circ} \mathrm{C} て ゙ ~ 2 h$ 焼成した後の $\operatorname{Pr}$ の添加量と 平均粒径との関係を示す. $\operatorname{Pr}$ の添加量の増加とともに $\mathrm{ZnO}$ の粒成長が急速に促進され，Pr 添加量が $0.5 \mathrm{~mol} \%$ の 付近で粒径は最大值の約 $20 \mu \mathrm{m}$ となった。しかし，それ 以上の添加では逆に粒成長は阻害された。特にPrを 5 


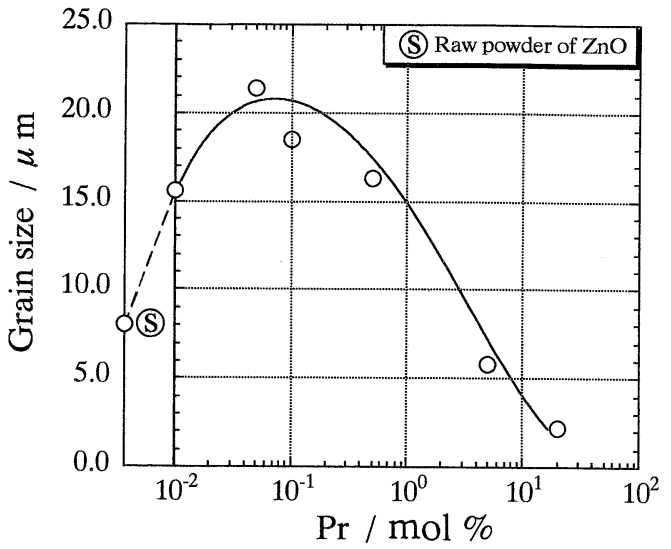

Fig. 1. Change of grain size with Pr concentration sintered in air.

$\mathrm{mol} \%$ 以上添加すると, $\mathrm{ZnO}$ の粒径は原料のそれとほとん ど同じであった。そして Prを $20 \mathrm{~mol} \%$ 以上添加した試料 では，焼結体の表面はかなり起伏が激しくなり $\mathrm{ZnO}$ 粒と 粒界析出物との区別がつけにくくなり，平均粒径の測定が できなかった。これらの実験結果は， $\mathrm{Bi}$ 系 $\mathrm{ZnO}$ バリス ターの場合に打ける $\mathrm{Bi}_{2} \mathrm{O}_{3}$ を微量に添加すると $\mathrm{ZnO}$ の粒 成長が促進すること及び添加量が $0.1 \sim 0.5 \mathrm{~mol} \%$ 以上では 粒成長が止まるという報告14) と傾向が一致する.

\section{2 粒 成 長}

図 2 (a)及び (b)に Pr $0.5 \mathrm{~mol} \%$ 添加した試料を $2 \mathrm{~h}$ 焼成 した際の粒成長速度と重量減少速度のアレニウスプロット をそれぞれ示す．粒成長速度と重量減少速度は各温度での $2 \mathrm{~h}$ 焼成したときの焼成前後の重量及び粒径の差を焼成時

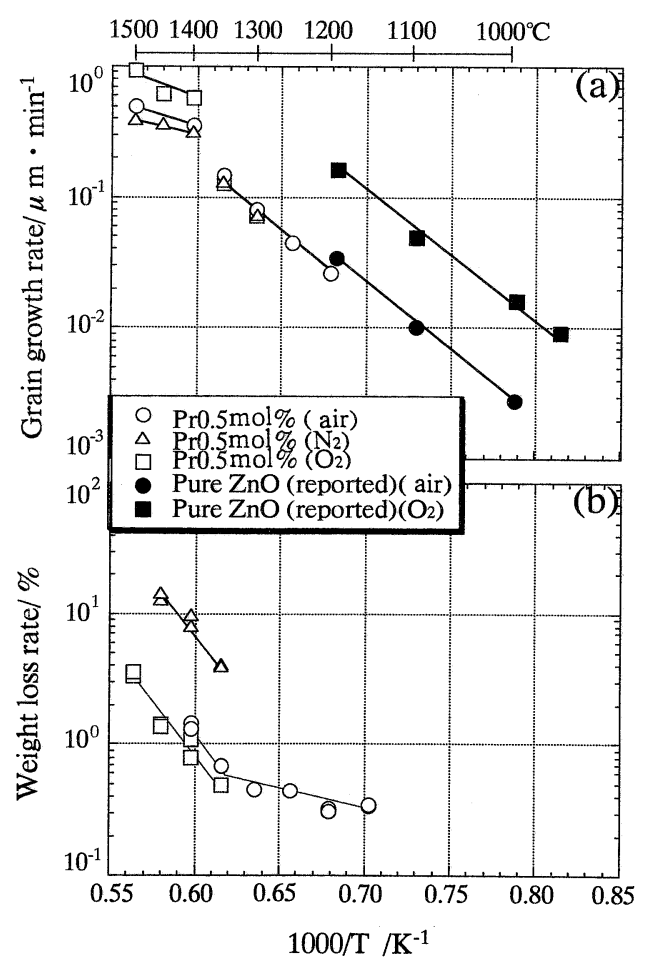

Fig. 2. Log (grain growth rate) and (b) $\log$ (weight loss rate) vs. reciprocal absolute temperature for $0.5 \mathrm{~mol} \% \mathrm{Pr}$-doped $\mathrm{ZnO}$.
間で割った值とした。したがって，ここではこの焼成時間 内での見掛けの平均速度を示している. より精密に求める には $2 \mathrm{~h}$ の間の重量及び粒径の変化をより細かく測定する 必要があるが, 今回は温度による变化の全体像を見るのが 目的であったので平均值を用いた。

粒成長速度と重量減少速度のそれぞれのプロットの傾き は $1350^{\circ} \mathrm{C}$ を境に大きな変化が見られる。図 2 (a)より， $1350^{\circ} \mathrm{C}$ 以下での活性化エネルギーは従来報告されている 純粋な $\mathrm{ZnO}$ の活性化エネルギー15) とよく一致しているこ とが分かる．ところが $1350^{\circ} \mathrm{Cを}$ 超えると，粒成長速度に 雲囲気依存性が現れると同時に活性化エネルギーが減少す ることが分かった。このことから $1350^{\circ} \mathrm{C} と 1400^{\circ} \mathrm{C}$ 間で 粒成長の機構が変化すると考えられる.

一方, 図 2 (b) に示したように重量減少速度と温度の関 係では $1350^{\circ} \mathrm{C}$ を超えると傾きが増加する．ここで重量変 化速度すなわち自由蒸発の速度 $J$ は以下の式で与えられ る16).

$$
J=\frac{\mathrm{d} m}{\mathrm{~d} t}=\frac{\alpha P_{\mathrm{e}}}{\sqrt{2 \pi M R T}}
$$

ここで， $\alpha$ は適応係数， $P_{\mathrm{e}}$ は平衡蒸気圧， $M$ は分子量で ある。 また， $P_{\mathrm{e}}$ は以下の式で与えられる17).

$$
P_{\mathrm{e}}=A \exp \left[-\frac{\Delta H_{\mathrm{s}}}{R T}\right]
$$

ここで， $A$ は定数， $\Delta H_{\mathrm{s}}$ は昇華熱である. したがって(1),(2) 式より

$$
\ln J=\ln \frac{\alpha}{\sqrt{2 \pi M R T}}+\ln A-\frac{\Delta H_{\mathrm{s}}}{R} \cdot \frac{1}{T}
$$

(3)式になり， $\log J$ と $1 / T$ が抢よそ直線関係になる。そ してその直線の傾きは $\Delta H_{\mathrm{s}}$ に相当し，図 $2(\mathrm{~b})$ の結果は, $\mathrm{ZnO} \rightleftarrows \mathrm{Zn}+1 / 2 \mathrm{O}_{2}$ の解離反応 ${ }^{18)}$ に伴う分子量の減少，す なわち主たる蒸発する物質が変化したことや, 蒸発の樣子 の変化を示唆している.

図 3 に $\mathrm{N}_{2}$, air 及び $\mathrm{O}_{2}$ 各雲囲気中 $1300^{\circ} \mathrm{C}$ で焼成した $\mathrm{Pr}$ $0.5 \mathrm{~mol} \%$ 添加試料の表面と内部の SEM 写真を示す。平 均粒径は試料の表面と内部とも約 $9 \mu \mathrm{m}$ 前後で大きな差は なく，また焼成雾聿気によらないことが分かった． $\mathrm{N}_{2}$ 雾 囲気中で焼成した試料の表面上には白い粒状の付着物が見 られるが，これは焼成中に飛散した $\mathrm{ZnO}$ あるいは $\mathrm{Pr}$ 酸 化物が冷却中に付着したものと思われる.

図 4 に各雲囲気中 $1400^{\circ} \mathrm{C}$ で焼成した Pr $0.5 \mathrm{~mol} \%$ 添加 試料の表面と内部の試料の SEM 写真を示す. 試料の表面 では雲囲気による粒径の変化が著しい. $\mathrm{N}_{2}$, air, $\mathrm{O}_{2}$ の順に 粒径が大きくなるとともに， $\mathrm{N}_{2}$ 中焼成の試料の表面では 明瞭な粒界相の析出が見られた。 また粒界相は焼成雲囲気 や試料の表面と内部によってその存在状態が異なることが 分かった. すなわち $\mathrm{N}_{2}$ 中焼成の試料の表面には多量の粒 界相が析出しているが， $\mathrm{O}_{2}$ 中焼成の試料の表面には粒界 相が見られない。一方, $\mathrm{O}_{2}$ 中焼成の試料の内部の微構造 を見ると，表面とは対照的に三重点に粒界相が多く偏析し ていることが分かる.

図 5 は $1400^{\circ} \mathrm{C}$ で焼成した Pr $0.5 \mathrm{~mol} \%$ 添加試料の内部 


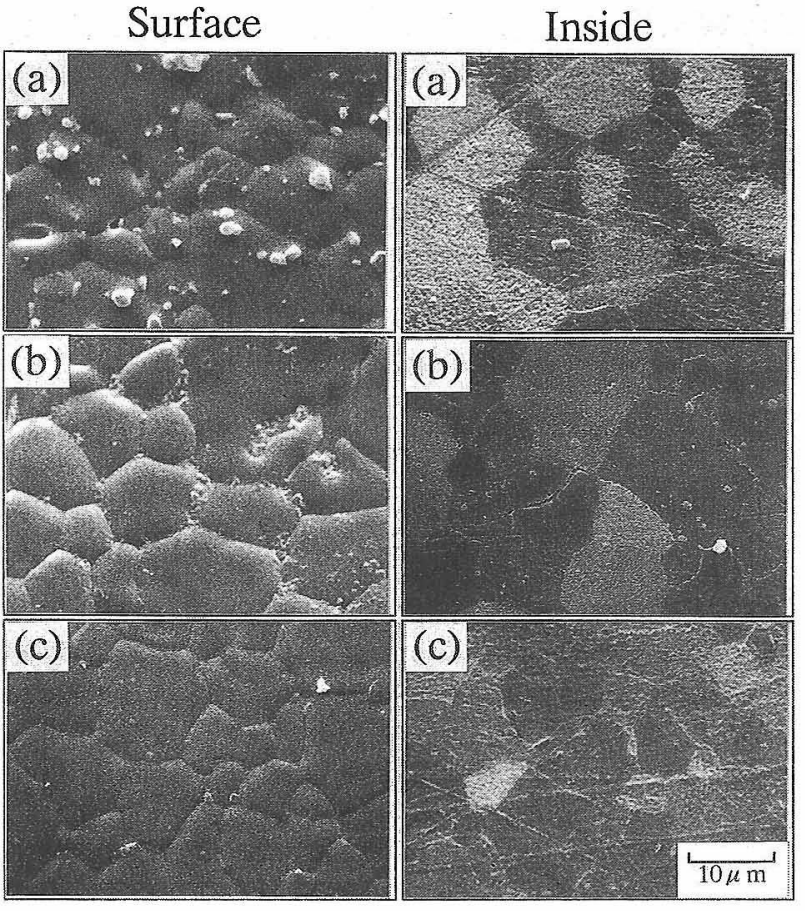

Fig. 3. SEM photographs of surface and inside of $0.5 \mathrm{~mol} \% \mathrm{Pr}$ doped $\mathrm{ZnO}$ sintered at $1300^{\circ} \mathrm{C}$ in (a) $\mathrm{N}_{2}$, (b) air and (c) $\mathrm{O}_{2}$.

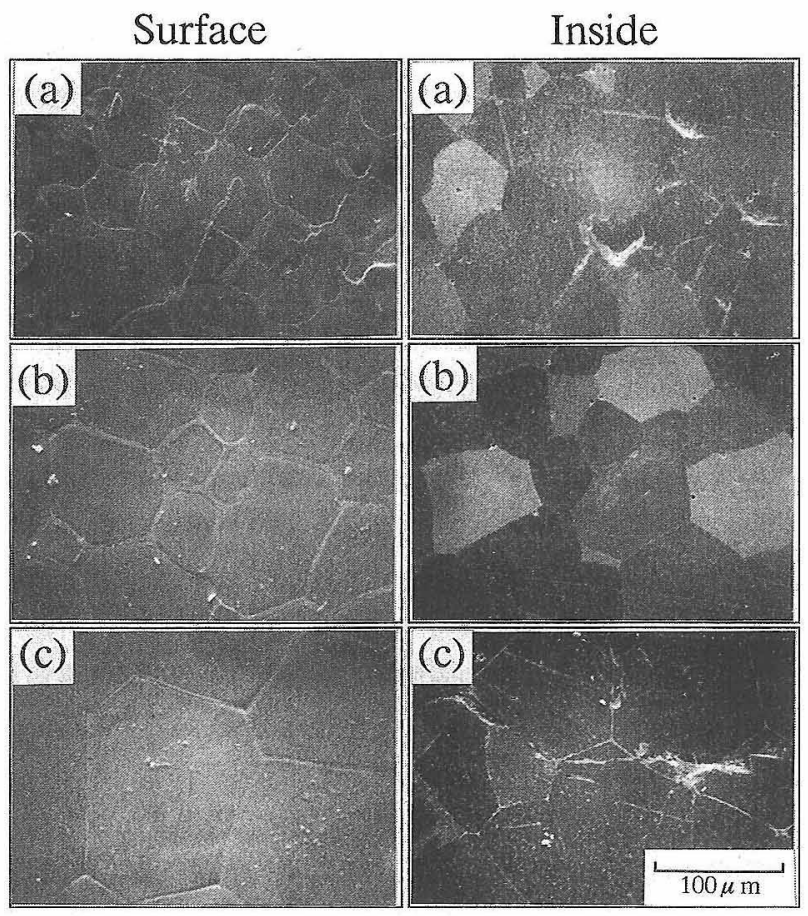

Fig. 4. SEM photographs of surface and inside of $0.5 \mathrm{~mol} \% \mathrm{Pr}-$ doped $\mathrm{ZnO}$ sintered at $1400^{\circ} \mathrm{C}$ in (a) $\mathrm{N}_{2}$, (b) air and (c) $\mathrm{O}_{2}$.

の三重点を拡大した写真である。内部の三重点の粒界相の 量は表面とは逆に $\mathrm{N}_{2}$, air, $\mathrm{O}_{2}$ の順に多く析出しているこ とが分かる。この内部の粒界相を組成分析した結果，Pr だけが検出され，Prの酸化物からなっていることが分 かった。このような表面と内部での濃度差は焼成雲囲気に より粒界相が移動することを示唆している。
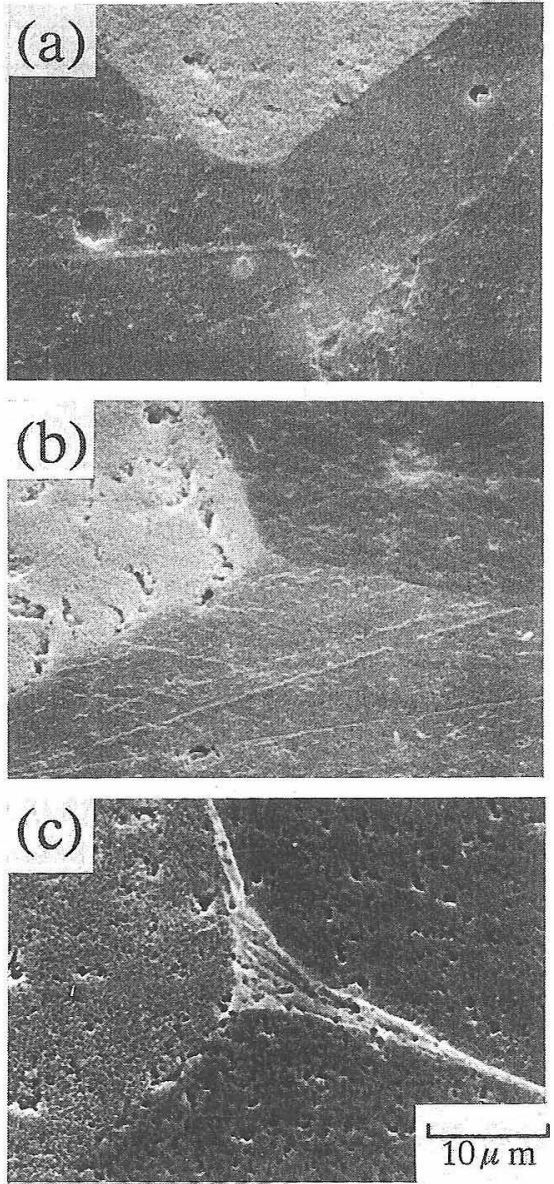

Fig. 5. SEM photographs of grain boundary of $0.5 \mathrm{~mol} \% \mathrm{Pr}$ doped $\mathrm{ZnO}$ sintered at $1400^{\circ} \mathrm{C}$ in (a) $\mathrm{N}_{2}$, (b) air and (c) $\mathrm{O}_{2}$.

図 6(a) は粒界相が顕著に見られた $\mathrm{N}_{2}$ 中 $1500^{\circ} \mathrm{C}$ で䡒成 した試料を $\mathrm{HNO}_{3}-\mathrm{HF}-\mathrm{HCl}-\mathrm{H}_{2} \mathrm{O}$ 系のエッチング液に浸 して $\mathrm{ZnO}$ 粒のみを溶出させて作製したスケルトンと呼ば れる網目構造の SEM 写真である。従来, $\mathrm{Pr}$ 系 $\mathrm{ZnO}$ バリ スターの二粒子間粒界には独立の粒界相の存在は確認しに くいと考学られていたが，Pr系 $\mathrm{ZnO}$ バリスターでも $\mathrm{Bi}$ 系の場合19) と同樣に粒界相が網目構造を形成しているこ とが分かった． $\mathrm{N}_{2}$ 及び $\mathrm{O}_{2}$ 中で焼成した試料のスケルト ンを粉砕して得た粉末の電子線回折像を図 $6(\mathrm{~b}),(\mathrm{c})$ にそ れでれ示す。 $\mathrm{N}_{2}$ 中で焼成した試料の粒界相の回折像から 面間隙を計算してみると, $\mathrm{Pr}_{2} \mathrm{O}_{3}$ であった。 $\mathrm{O}_{2}$ 中で燒成 した試料の粒界相には $\mathrm{N}_{2}$ 中で焼成の場合と同様に $\mathrm{Pr}_{2} \mathrm{O}_{3}$ が見られたが，また，同一試料のその他の粉碎小片によっ ては $\operatorname{Pr}_{6} \mathrm{O}_{11}$ も見られた。攼たスケルンをEDS 及び ICP で分析した結果， $\mathrm{N}_{2}, \mathrm{O}_{2}$ ぞちらの雾团気で烧結した 場合でも Pr 加ら構成されて抢り，Zn は Pr 量に対し $1 \%$ 程度含まれていることが分かった．しかしながら，これは $\mathrm{ZnO}$ 粒との分離が難しく混入したからであると考えられ る。

雾囲気による粒界相の存在状態の相違が出ることを困 3 で述べた。添加した原料 $\operatorname{Pr}_{6} \mathrm{O}_{11}$ は高温での焼成中に $\mathrm{Pr}_{2} \mathrm{O}_{3}$ に解離，還元されるため，焼成後の試料中に存在す る $\mathrm{Pr}$ は $\mathrm{Pr}_{2} \mathrm{O}_{3}$ であると考えられる。しかしながら $\mathrm{O}_{2}$ 中 

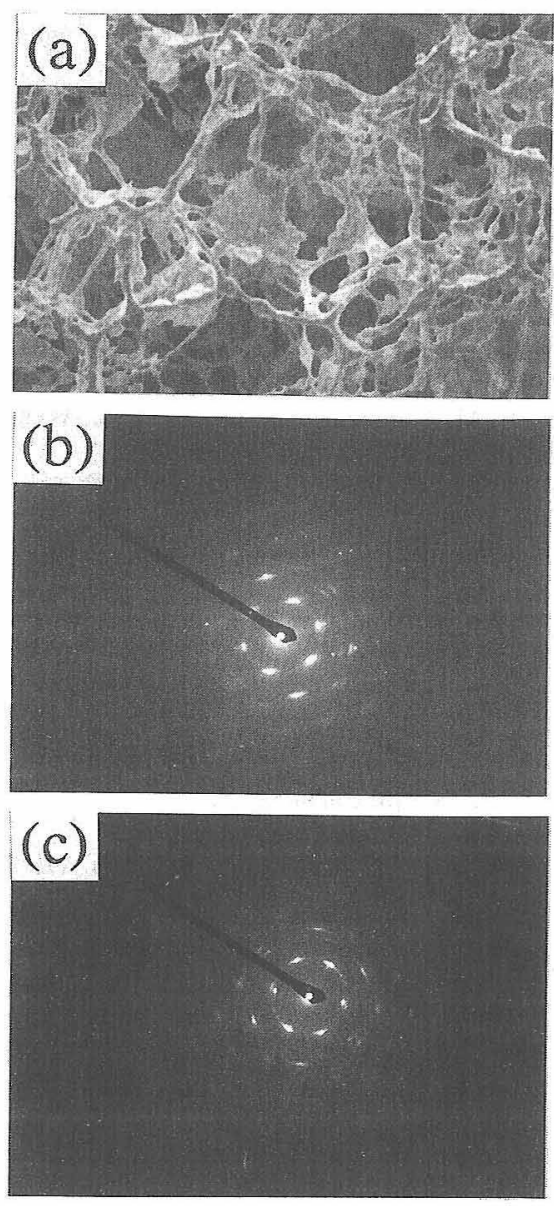

Fig. 6. SEM photograph and electron diffraction images of grain boundary phase in specimens sintered in $\mathrm{N}_{2}$ and $\mathrm{O}_{2}$, (a) isolated grain boundary phase, (b) $\operatorname{Pr}_{2} \mathrm{O}_{3}$ in $\mathrm{N}_{2}$, (c) $\operatorname{Pr}_{2} \mathrm{O}_{3}$ and $\operatorname{Pr}_{6} \mathrm{O}_{11}$ in $\mathrm{O}_{2}$.

で焼成した試料中には $\mathrm{Pr}_{2} \mathrm{O}_{3}$ だけではなく $\mathrm{Pr}_{6} \mathrm{O}_{11}$ も存在 することが X 線回折や電子線回折像から確認された。こ れは $\mathrm{O}_{2}$ の存在する雲囲気下では $\operatorname{Pr}_{6} \mathrm{O}_{11}$ の高酸化状態と $\mathrm{Pr}_{2} \mathrm{O}_{3}$ の低酸化状態が共存していることを示している.今 回の分析では両者の共存するする試料中の場所は特定でき なかった。

air 中 1300,1400 及び $1500^{\circ} \mathrm{C}$ で燒成した試料の平均粒径 と焼成時間との関係を図 7 に示す。一般にセラミックスの 粒成長速度は平均粒径 $G$ と時間 $t$ の間には次のような関 係が成立する。

$$
G=G_{0} t^{1 / n}
$$

図からいずれの温度も $\log G$ と $\log t$ は直線関係で, (4)式 が成り立っている。 nについて調べると， $1300^{\circ} \mathrm{C} て ゙ は 4.5$,

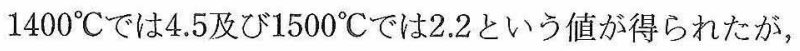
これは従来の純粋な $\mathrm{ZnO}$ の粒成長について $1200 \sim 1400^{\circ} \mathrm{C}$ の範囲で報告されている $n=4$ の值 ${ }^{20) ~ 22) ~}$ 之一致している. 一方, $1500^{\circ} \mathrm{C}$ では $n$ の值が半分以下となり，この温度の 前後で粒成長の機構に大きな変化があることを示唆してい る.

$\operatorname{Pr} 0.5 \mathrm{~mol} \%$ 試料の混合粉末を $\mathrm{N}_{2}$ ガスを流しながら高 温DTA を用いて熱分析を行った結果を図 8 に示す。測定 は $1500^{\circ} \mathrm{C}$ まで昇温後, $10^{\circ} \mathrm{C} / \mathrm{min}$ で $1200^{\circ} \mathrm{C}$ な゙降温させて

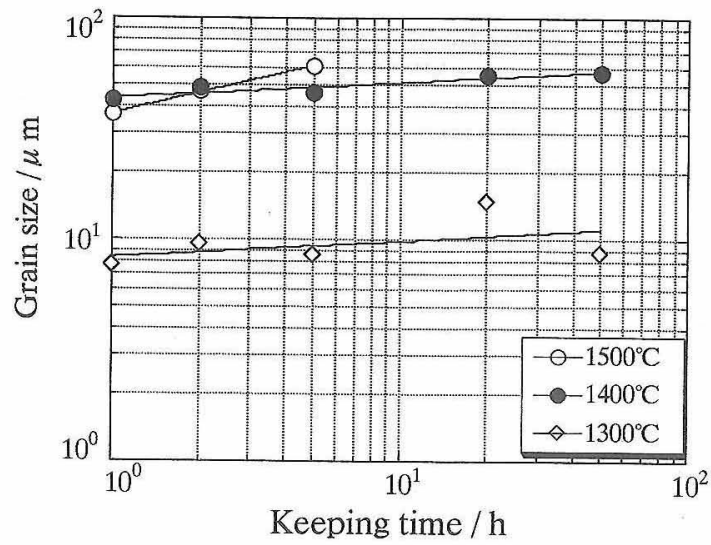

Fig. 7. Change of grain size of $0.5 \mathrm{~mol} \% \mathrm{Pr}$-doped $\mathrm{ZnO}$ with keeping time in the air.

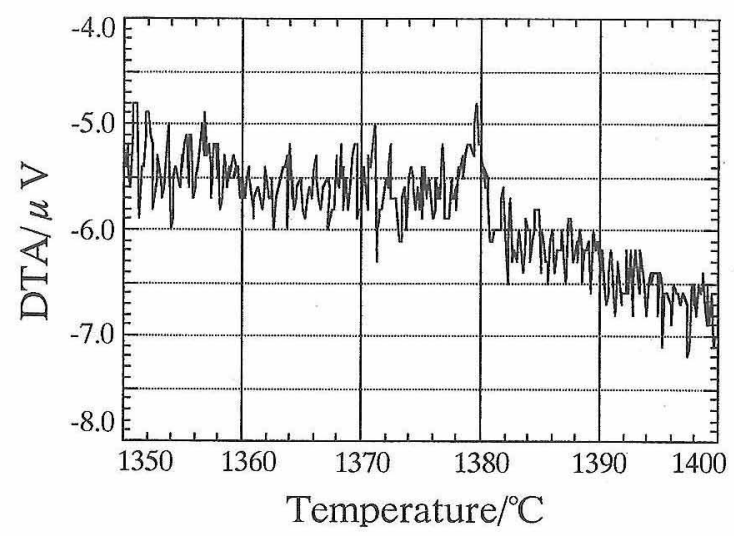

Fig. 8. DTA curve of 0.5 mol\% $\mathrm{Pr}$-doped $\mathrm{ZnO}$ powder in air on cooling at a rate of $5^{\circ} \mathrm{C} / \mathrm{min}$.

行ったが，その結果，降温時に $1380^{\circ} \mathrm{C}$ 付近に極めて小さ い発熱のピークが倹出された。 な初昇温時にも吸熱ピーク が検出されると考劣られるが，そのピークは極めて微弱な ため，今回の測定ではノイズに埋もれて検出されなかっ た。しかしながら図 8 に示した降温時の発熱ピークは同 一試料を 3 回測定しても，3 回とも明確に確認され，再現 性は十分であると考党られる。この原因として微量の夜相 の存在や何らかの相転移などが考えられる. $\mathrm{ZnO}$ 単味の 場合にはこのようなピークが見えないことから粒界相の Pr 化合物に起因するものと考光れる.

\section{4. 総 括}

$\operatorname{Pr}$ 系 $\mathrm{ZnO}$ バリスターにおいて，Pr 添加による粒成長 の促進や粒界部にPrが偏析することに基づいて，焼成温 度, 雾囲気, Pr の濃度, 焼成時間などを変化させ， $\mathrm{ZnO}$ の粒成長や粒界相に及ぼす影響について調べた。その結果 以下のことが明らかになった。

(1) $\mathrm{ZnO}$ の粒成長は $\mathrm{Pr}$ の添加量の増加とともに促進 されたが，Prの濃度 $0.5 \mathrm{~mol} \%$ 付近で粒径は最大值の約 $20 \mu \mathrm{m}$ となり, Pr $0.5 \mathrm{~mol} \%$ 以上添加すると逆に粒成長 は阻害された。 
（2）焼成温度による粒成長速度や重量減少速度は $1350^{\circ} \mathrm{C}$ を境に大きな変化があり, $1350^{\circ} \mathrm{C}$ 超えると粒成 長の活性化エネルギ一は減少, 重量減少速度は増加するこ とが分かった。

（3）平均粒径や粒界相の存在状態は雲囲気によらな かったが $1350^{\circ} \mathrm{C}$ 以上で $\mathrm{N}_{2}$ 中焼成試料は表面に多量の粒界 相が析出し, $\mathrm{O}_{2}$ 中焼成試料は内部の三重点に多く偏析し た. TEM 及びEDS で観察されたこの粒界相はほとんど $\operatorname{Pr}$ の酸化物であることが分かった.

（4）（4）式の粒成長速度式中の指数 $n$ の值は $1400^{\circ} \mathrm{C}$ を 超えると4.5から 2.2 に減少した。 また, Pr $0.5 \mathrm{~mol} \%$ 添加 $\mathrm{ZnO}$ 試料の DTA は冷却中の $1380^{\circ} \mathrm{C}$ 付近で発熱ピークを 示した。これらの結果から， $1350^{\circ} \mathrm{C}$ 付近を境に粒界相で ある $\operatorname{Pr}$ の酸化物に大きな変化があると考えられ，その一 因として液相の生成が示唆された。

謝辞 本研究の実行に当たっては(株)富士電機総合研究所 の向江和郎氏及び(株)TDK 基礎研究所の淀川正忠氏に有益な討 論を頂きました。

\section{文献}

1) M. Matsuoka, Jpn. J. Appl. Phys., 10, 736-46 (1971).

2) J. Wong and W. G. Morris, Am. Ceram. Soc. Bull., 53, 81620 (1974).

3) L. M. Levinson and H. R. Philipp, Am. Ceram. Soc. Bull., 65, 639-46 (1986).

4) T. K. Gupta, "Tailoring Multiphase and Composite Ceramics”, Plenum Press, NY (1986) pp. 493-507.
5) T. Asokan, G. N. K. Iyengar and G. R. Nagabhushana, J. Am. Ceram. Soc., 70, 643-50 (1987).

6) H. Cerva and W. Russwaurm, J. Am. Ceram. Soc., 71, 52230 (1988).

7) B. Hoffman and V. Schwing, "Advances in Ceramics", Vol. 1, Ed. by L. M. Levinson, Am. Ceram. Soc., OH (1981) p. 343.

8) P. M. Vipin, V. V. Sanjaynath and H. K. Varma, Ceram. International, 16, 319-23 (1990).

9) K. Mukae, Am. Ceram. Soc. Bull., 66, 1329-31 (1987).

10) K. Mukae and I. Nagasawa, "Advances in Ceramics, Vol. 1", Ed. by L. M. Levinson, Am. Ceram. Soc., Westerville, $\mathrm{OH}$ (1981) pp. 331-42.

11） K. Tsuda and K. Mukae，セラミックス論文誌，97，121118 (1989).

12) A. B. Alles and V. L. Burdick, J. Appl. Phys., 70, 6883-90 (1991).

13) A. B. Alles, R. Puskas, G. Callahan and V. L. Burdick, $J$. Am. Ceram. Soc., 76, 2098-102 (1993).

14) J. Wong, J. Appl. Phys., 51, 4453-59 (1980).

15) S. K. Dutta and R. M. Spiggs, J. Am. Ceram. Soc., 53, 61-62 (1970).

16) J. P. Hirth, "Metal Surfaces: Structure, Energetics and Kinetics", ASM, Metals Park, OH (1962).

17） R. A. Swalin, “固体の熱力学”, コロナ社 (1963) p. 83.

18）イ・エス・クリコフ, “酸化物の熱力学”, 日ソ通信社 (1987) p. 242.

19) E. Olsson, G. Dunlop and R. Oesterlund, J. Am. Ceram. Soc., 76, 65-71 (1993).

20) G. C. Nicholson, J. Am. Ceram. Soc., 48, 214-15 (1965).

21) T. K. Gupta and R. L. Coble, J. Am. Ceram. Soc., 51, 521-25 (1968).

22) T. K. Gupta and R. L. Coble, J. Am. Ceram. Soc., 51, 525-28 (1968). 